\title{
The Effect of STAD-Based Module Used on Writing the Report Text of Observation Results
}

\author{
I Nisja, S Rismen, L H A Mana, T F Yusandra \\ STKIP PGRI Sumatera Barat \\ \{indrianinisja192@gmail.com¹, syefna@gmail.com², lirahayuam@gmail.com³, \\ Tfujita.yusandra@yahoo.co.id $\left.{ }^{4}\right\}$
}

\begin{abstract}
The problem found in this study is that the students have difficulty in developing idea(s) in writing. The purpose of this study was to determine the effect of the use of observation report writing text skills through the modul berbasis STAD-based STAD cooperative learning model on the tenth grade students of SMAN 3 Padang. This quantitative research uses a post-test only control group design design in which the samples are gotten by using simple random sampling technique. The data in this study was the scores of writing the observation report. Those data are gathered by using performance text as the instrument. Then, after collecting the data, they were analyzed. The results of data analysis are that : (1)The level of skill in writing the observation report text before using the STAD type modul berbasis STAD-based cooperative learning modul obtained an average score of 65,24 . it means that the scores are in the level 55-65\% mastery with "Enough (C)" qualification. (2) the level of skill in writing the observation report text after using the STAD type modul based STAD-based cooperative model gained an average score of 72,62 , which was at the $65-75 \%$ mastery level in More than Enough (Ldc) qualifications. (3) It can be concluded that the STAD type modul berbasis STAD-based cooperative model influences the writing skills of observation reports text with $\mathrm{t}_{\text {count }}>\mathrm{t}_{\text {table, }}$, namely $(3.41>1.67)$.
\end{abstract}

Keywords: STAD Based Module, Writing, Observations` Report Text

\section{INTRODUCTION}

Indonesian is one of the subjects that must be studied in every education level, one of them is in High School (SMA / MA). The language skills of students demanded to include interpreting, constructing, recreating, developing, and analyzing. One aspect of language that must be mastered by students in the 2013 curriculum is to construct, and lower it down to indicators of writing text. Writing is one of the main cognitive challenges because this skill requires an examination of the ability to remember, speak, and think at once.

One of the Writing skills that must be mastered by class X students at the level of High School (SMA) is writing observations ' report text. Based on the above problems, efforts need to be made to improve students 'skills in writing observation report texts, including learning models that can stimulate students' thinking ability. One of the efforts is by implementing the Student Teams 
Achievement Division (STAD) learning model. By using STAD model, students are more active in discussing the text of the Observation Results Report. Previous research has proven that the STAD method is able to improve student learning outcomes. The research was conducted by Fauziah, Hudallah, \& Supraptomo, 2015; Tatalia, 2016; Winarsih 2015; Lubis, 2012; Pujianto, Nuryatin, \& Subyantoro, 2015. The results of the study showed that the STAD (Student Team Achievement Division) learning model is performed well according to the planned learning syntax [1]. The ability of each student in learning and teaching the material / subject matter to other friends in the group can take place well, so that his friend is able to understand and solve problems well. STAD type cooperative learning makes students interact and discuss each other in generating effective problem solving strategies, fostering the ability of cooperation, critical thinking, and developing students' social attitudes [2]. Based on the results of Nugroho's research, through cooperative learning several findings were obtained including teachers in managing learning well enough, and can increase the activity of teachers and students during learning, teachers are able to practice process skills well, turning teacher-centered learning into student-centered learning. The ability of each student in learning and teaching the material / subject matter to other friends in the group can take place well, so that he can understand and solve problems well [3].

The STAD learning model is a learning model that forms students in groups, each group consists of 4-5 students who have various abilities ranging from low to high, the teacher gives a quiz to students and the teacher gives rewards or awards to the group that wins or gets the highest score. Working together in groups can make students more active in learning. This is certainly in accordance with the nature of learning based on constructivist views in cooperative learning. That, according to constructivist views in cooperative learning, students will more easily understand and find difficult concepts when they talk to each other about these problems [4].

The use of the STAD type cooperative learning model can be helped by using STAD-based modules. By using STAD-based modules it is hoped that it can provide variations in the application of the STAD type cooperative model and arouse students' interest in the skills of writing observational report texts. In general the text of the observation includes in the form of description and factual texts that can be scientific or informative. The form of the text of the observation results in the form of reports of events or events, activity reports, observation reports, travel reports, and interview reports. Text that contains factual form of expressing experiences, knowledge, feelings, and sensations through written language to be read or understood by others and has its own motivation for readers is called the text of observation [5].

The formulation of the problem in this study is as follows. First, how is the skill in writing an observation's report text in the 2013 curriculum before using STAD-based modules? Second, how is the skill to write observation report text in the 2013 curriculum after using STAD-based modules? Third, how does the influence of the use of STAD-based learning modules on learning to write text on observational reports on the 2013 curriculum?

Observation's report text is one of the teaching materials that can improve students' writing skills. The text of the observation results is a form of report from the results of observations made by students in learning activities carried out in the classroom. Each text has its own structure that is different from each other. This is in accordance with the opinion of Gultom which states that each text has its own structure which is different from each other. The text structure is a reflection of the thinking structure

Report text or report text is a text whose contents describe something as it is as a result of systematic observation or analysis. The text of the observation report [6] is also referred to as classification text because the text contains a classification of the types of things based on certain criteria. In an effort to teach students to be more critical in observing objects around them, then learning the observation report text needs to be done in schools. Learning the text of the observation report aims to improve students' cognitive abilities. Increased cognitive abilities will also trigger an increase in affective and psychomotor aspects if realized in the right learning concept.

Planning learning to write observational report text needs to pay attention to the details of prewriting, writing, and post-writing activities. In prewriting activities, it is necessary to pay attention to observation or writing activities based on student observation of the observed object. Selection 
of the topic of observation, direct writing in class or indirect, and editing of individuals or groups, need to be considered to achieve maximum writing results [7].

The text structure of the report is an observation that is a general definition, a section description, and a description of benefits. The linguistic characteristics of the report text are observations, that is, using nouns, verbs, copula, words that state groupings and technical words. Student Teams Achievement Division (STAD) is one method or approach in cooperative learning that is simple and good for teachers who are just starting to use a cooperative approach in class, STAD is also an effective cooperative learning method. All students exchange ideas and help each other's members to get the best score and get an award from the teacher.

Research on the writing skills [8] of the report's observation text using modules in cooperative learning type Student Teams Achievement Division (STAD). Thus, a study was conducted with the title "The use of STAD-based modules on learning to write text on reports on observations".

\section{RESEARCH METHOD}

This type of research is quantitative. The research method used is the experimental method with the true experimental method in the form of a post-test only control group design. The development of post-test only control group design is the simplest design of the actual experimental design, because the respondents were actually randomly selected and treated and there was a group of controllers [9] [10].

The selection of research samples was carried out by simple random sampling technique. Simple random sampling is done because the taking of sample members from the population is done randomly regardless of the strata that exist in that population. The variables in this study are two variables, namely the independent variable is the module-based cooperative model Student Teams Achievement Division (STAD), STAD-based, and the dependent variable is the skill of writing the observation report. The research instrument used was performance tests. This test is useful for measuring the level of writing skills of a student's observation report before and after using a STAD-based module [11].

Data collection techniques in this study were conducted in the control class and experimental class. In the control class, one meeting is carried out in the following steps: First, students are given material about writing the text of the observation report. Second, students working on the initial test (pretest) write the text of the observation report with the theme "Animals", after completion of the work sheet students are gathered and examined according to the indicators assessed.

In the experimental class carried out by the following steps. First, students are given material about writing a report report text. Secondly, students were given treatment by practicing writing the report text of the observation results using a cooperative model based on STAD-based Student Teams Achievement Division (STAD). Third, students working on the final test (posttest) write an observation report text with the theme "Animals". Fourth, after completion of the sheets of student writing collected and examined based on indicators.

The data analysis technique used is as follows. First, read the text of the observation report written by the students. Second, give a score on the report text of the observation based on the aspects studied. Third, processing scores into values using the percentage formula. Fourth, present the value obtained in the frequency distribution table. Student grades are written and sorted from highest to lowest. Fifth, determine the average value of the skill in writing the report report text before and after using the module based on the Sixth STAD, classifying the skill of writing report text on the observation results of class X SMAN 3 Padang by using a module based on Student Teams Achievement Division (STAD) using a scale of 10 Seventh, make a diagram of the skill in writing report text on the results of observation of class X students of SMAN 3 Padang before and after using the STAD-based Student Teams Achievement Division (STAD). Eighth, test the normality and homogeneity of data. Ninth, discuss the results of data analysis and make conclusions. 


\section{RESULT AND DISCUSSION}

Text Writing Skills Reports on Observation Results Without Using Cooperative Models Student Teams Achievement Division (STAD) Assisted by Module X Grade Students of SMAN 3 Padang. Based on the data obtained an average of 65.24. Then it was concluded that the level of mastery of writing report text skills of observation results without the use of cooperative learning Student Teams Achievement Division (STAD) type assisted module X grade students of SMAN 3 Padang were at the mastery level of $56-56 \%$ with sufficient qualifications (C). Furthermore, the classification of report writing skills in the results of observation of class X students of SMAN 3 Padang without using the cooperative learning model type Student Teams Achievement Division (STAD) assisted by modules based on the scale of 10 . Obtained a picture of learning outcomes of students who qualify perfectly, very well, less, bad, and very bad. Students who get good qualification scores are 2 people $(5.71 \%)$. Students who get grades with more than enough qualifications are 20 people $(57.14 \%)$. Students who obtain grades with sufficient qualifications are 7 people $(20 \%)$. Students who get grades with almost enough qualifications as many as 6 people $(17.15 \%)$.

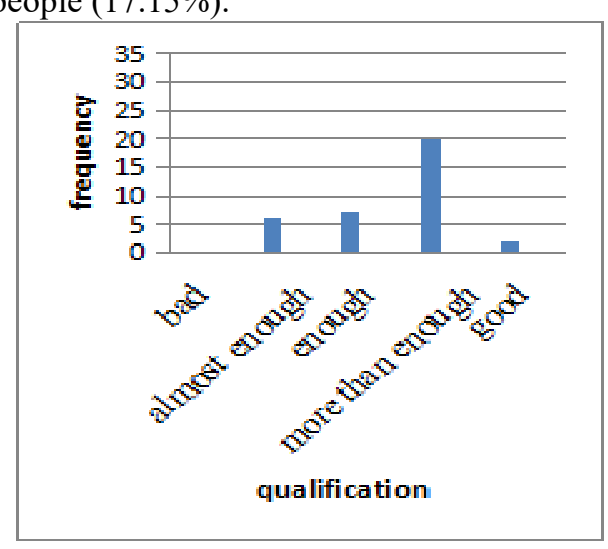

Diagram 1. Skills in Writing Text of Report on Observation Results without Using Cooperative Learning Model Student Teams Achievement Division (STAD) Assisted by Module X Class Students of SMAN 3 Padang. Text Writing Skills Reports of Observation Results Using Cooperative Model Student Teams Achievement Division (STAD) Assisted by Module X Grade Students of SMAN 3 Padang.

Based on the data above, the calculated average is 72.62. Then it was concluded that the level of mastery of the skills in writing the text of the observation report by using cooperative learning type Student Teams Achievement Division (STAD) assisted by module class X SMAN 3 Padang was at the level of $66-75 \%$ more than Enough $(\mathrm{LdC})$. the classification of report writing skills in the results of observation of $\mathrm{X}$ grade students of SMAN 3 Padang by using cooperative learning model Student Teams Achievement Division (STAD) assisted by a module based on scale 10 obtained an overview of student learning outcomes using assisted cooperative learning model Student Teams Achievement Division (STAD) module, for all indicators of qualified students get less, less, bad, and very bad grades. Students who get perfect qualification scores are 1 person $(2.86 \%)$. Students who obtain excellent qualifications of 2 people $(5.71 \%)$. Students who get good qualification scores are 8 people $(22.86 \%)$. Students who obtain grades with more than enough qualifications are 18 people $(51.43 \%)$. Students who obtain grades with sufficient qualifications are 3 people $(8.57 \%)$. Students who obtain grades with almost enough qualifications as many as 3 people $(8.57 \%)$. 


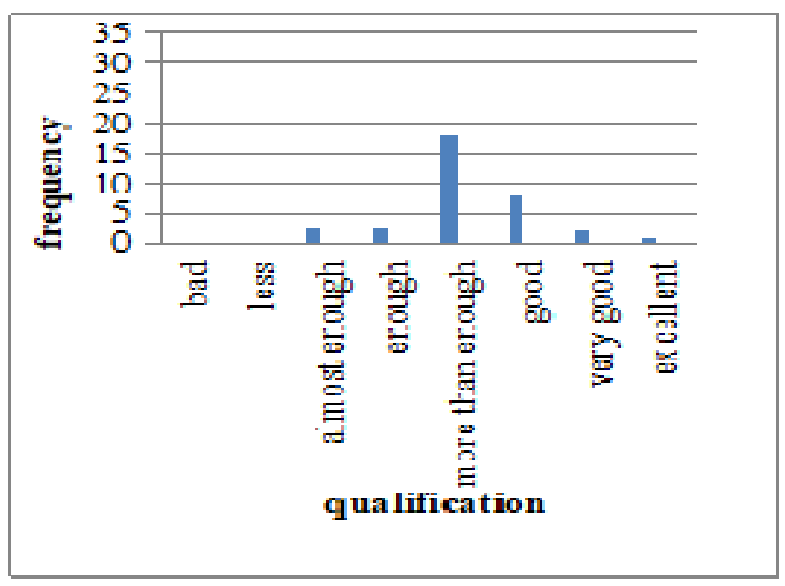

Diagram 2. Skills in Writing Text Reports on Observation Results Using Cooperative Learning Models Student Teams Achievement Division (STAD) Assisted by Module X Grade Students of SMAN 3 Padang. The Influence of Cooperative Learning Model Type Student Teams Achievement Division (STAD) Assisted by Modules in Learning Writing Text Report on Observation Results of Grade X Students of SMAN 3 Padang

The results of data analysis in this study indicate that in general the skills of writing report text on the observation results of class X SMAN 3 Padang without using the cooperative learning model of the student-assisted team achievement division (STAD) module obtain a calculated average of 65.24 at the mastery level $56-56 \%$ are sufficiently qualified (C). Meanwhile, the skill of writing report text as a result of observation of class X SMAN 3 Padang by using cooperative learning model type student assisted team achievement division (stad) obtained an average of 72.62 is at the mastery level 66-75\% qualifies More than Sufficient (LdC).

Based on the results of the t-test it can be concluded that there is an influence on the use of cooperative learning models of the Student Teams Achievement Division (STAD) type assisted by modules of class X SMAN 3 Padang because of tcount $>t$ table $(3.41>1.67)$.

Based on the results of data analysis can be described the skill of writing the text of the observation report without using a cooperative model of the First Assisted Team Achievement Division Student type, for indicator 1 (general definition) is quite sufficient, because the calculated average is 60 in the range of 56-65\%., for indicator 2 (description section) is more than enough, because the average calculation is 67.62 in the range of $66-75 \%$. Third, for indicator 3 (decryption of benefits) is quite sufficient because the average count of 61.90 is in the range of $55-65 \%$. Fourth, for indicator 4 (verb) is classified as more than enough because the average count is 71.42 in the range of $66-75 \%$.

Furthermore, the text writing skills of the observation report using the cooperative model of the First Student Team Achievement Division Help module, for indicator 1 (general definition) are sufficient, because the average calculation is 59.04 in the range of 56-65\%. Second, for indicator 2 (description section) is more than enough, because the average count of 67.62 is in the range of 66$75 \%$. Third, for indicator 3 (decryption of benefits) is quite sufficient because the average count of 61.90 is in the range of 55-65\%. Fourth, for indicator 4 (verb) is classified as more than enough because the average count is 71.42 in the range of $66-75 \%$.

\section{CONCLUSIONS}

Based on the results of data analysis and discussion, the following three points can be concluded. First, the skill in writing the report text skills of the observation results of class X SMAN 3 Padang without using the cooperative learning model type Student Teams Achievement Division (STAD) assisted by the module obtained an average score of 65.24 which is at the mastery level of $55-65 \%$ in the Enough qualification (C).

Secondly, the report writing skills of the results of observation of class X students of SMAN 3 Padang using the cooperative learning model type Student Teams Achievement Division (STAD) 
assisted by the module obtained an average score of 72.62 which is located at $65-75 \%$ mastery level in qualifications More than Enough ( $\mathrm{LdC})$.

Thirdly, based on the t-test it was concluded that there was an influence on the use of cooperative learning models of the Student Teams Achievement Division (STAD) type assisted by modules of class X SMAN 3 Padang because of tcount $>t$ table $(3.41>1.67)$, so the null hypothesis was rejected and alternative hypothesis accepted.

\section{REFERENCES}

[1] R. G. Tatalia, "Pengaruh Model Pembelajaran Kooperatif Tipe STAD terhadap Kemampuan Menulis Teks Berita Siswa Kelas VIII SMP Negeri 1 Panti," Gramatika, vol. 3, Nomor 1, pp. $59-73,2017$.

[2] A. D. Winarsih, "PENINGKATAN KEMAMPUAN MENULIS TEKS PROSEDUR KOMPLEKS MELALUI MODEL PEMBELAJARAN STAD ( STUDENT TEAM ACHIEVEMENT DIVISION ) PADA KELAS X-IPA 3 SMAN CANDIPURO LUMAJANG," Inov. Pembelajaran, vol. 1, no. November, pp. 122-132, 2015.

[3] U. Nugroho and S. S. Edi, "Penerapan pembelajaran kooperatif tipe stad berorientasi keterampilan proses," vol. 5, pp. 108-112, 2009.

[4] H. A. Lamba, "Model STAD dan Gaya Kognitif terhadap Hasil Belajar Fisika Siswa SMA," no. 15 , pp. 122-128, 2000.

[5] M. Idris and I. Zulaeha, "Seloka : Jurnal Pendidikan Bahasa dan Sastra Indonesia Keefektifan Buku Pengayaan Menulis Teks Hasil Observasi Bermuatan Multikultural Berbasis Proyek Baca Tulis untuk Peserta Didik SMP Abstrak," Seloka, vol. 6, no. 73, pp. 187-199, 2017.

[6] S. P. MacDonald, "The language of journalism in treatments of hormone replacement news," Writ. Commun., 2005.

[7] I. S. Wilujeng and I. Suyitno, "Pengaruh Strategi Pemetaan Semantik terhadap Hasil Belajar Menulis Teks Laporan Hasil Observasi Siswa dengan Gaya Kognitif yang Berbeda," Pendidik. Teor. Penelitian, dan Pengemb., vol. 2 Nomor 9, pp. 1231-1237, 2017.

[8] A. Saricoban, "Translation to Test Vocabulary and Language Skills," Procedia - Soc. Behav. Sci., 2012.

[9] J. A. Maxwell and L. E. Reybold, "Qualitative Research," in International Encyclopedia of the Social \& Behavioral Sciences: Second Edition, 2015.

[10] K. Saddhono, N. E. Wardani, and C. Ulya. "Sociopragmatic approach on discourse structure of friday prayer's sermon in java and madura island." J. of Lang and Lit, vol. 6 no. 1 pp 2629, 2015.

[11] R. K. Yin, Applications of case study research. 2003. 